DOI: 10.2478 /ausp-2020-0011

\title{
Verbal Humour in Screen Translation: Officer Crabtree's Case with the Fronch and Hungarian Longwodge
}

\author{
Zsuzsanna AJTONY \\ Sapientia Hungarian University of Transylvania (Cluj-Napoca, Romania) \\ Department of Humanities, Miercurea Ciuc \\ ajtonyzsuzsa@uni.sapientia.ro
}

\begin{abstract}
The present study aims to gain insight into the translation of audiovisual humour displayed in the verbal manifestations of Officer Crabtree, the fictional character in the BBC sitcom 'Allo 'Allo! (1982-1992), especially focusing on its Hungarian dubbed version of the series. Being a research domain with insights from audiovisual translation (AVT), humour studies, and discourse analysis, the article introduces the reader to AVT, more particularly, to dubbing, to research carried out in the domain of audiovisual humour, and to humour studies, especially focusing on incongruity and superiority theory. These theoretical elements are applied in the analysis of the corpus comprising the English voice track as source text (ST) and its Hungarian counterpart as target text (TT), highlighting the humorous effects achieved in both of them and especially pointing at the creative solutions translators resorted to in rendering the idiosyncratically mangled English texts into Hungarian. The analysis aims to provide counterexamples to the frequent claim that verbal humour is untranslatable.
\end{abstract}

Keywords: verbal humour, situation comedy, broken language, audiovisual translation, dubbing

\section{Introduction}

British humour has its special character, frequently misunderstood by its recipients, members of other nations or cultures. Still, British audiovisual humour, especially English situation comedies (sitcoms) travel extremely well on the European continent in spite of the non-English speaking audiences, due to the brilliantly dubbed or subtitled versions of the English screenplays. This study wishes to highlight one slice of Hungarian audiovisual translation (AVT) - namely, by the comparative analysis of the English and its Hungarian dubbed version of the BBC 
sitcom 'Allo 'Allo!, especially focusing on the verbal humour found in one specific character, Officer Crabtree's utterances and their Hungarian dubbed version.

The present study was greatly inspired by Dirk Delabastita's article entitled Language, Comedy and Translation in the BBC Sitcom 'Allo 'Allo! (2012), which discusses the hybrid language variants of the series and the possibilities of their translation as they appear in the Dutch subtitles and in the French dubbing. After a short presentation of the plot of the series, Delabastita's article turns to the analysis of the forms of comedy present in the sitcom, stressing that the series was initially planned to be a parody of war-based films and TV dramas. In Allo Allo!, creators and screenwriters David Croft and Jeremy Lloyd offer a caricature of World War II and of the typical national stereotypes presented through the French, German, English, and Italian characters present in the series.

The forms of comedy present in the series include: "absurdity, bawdiness and double entendre, scatological jokes, referential ambiguity and wordplay, misidentifications, mix-ups, silly disguises, playing with the viewers' expectations (recurrent catchphrases and situations), visual gags and comedy based on deliberate clumsy actions (slapsticks)" (Delabastita 2012: 196). Language appears to be an excellent means to convey humour in all the episodes of the series as the viewer of the original English version is able to detect a hybrid mixture of English-language varieties standing for English, French, German, and Italian, depending on what nationality character the speaker is. In other words, all the characters use English in their utterances, but, depending on their nationality, they pronounce their English with a special accent: e.g. the French characters speak English with a French accent, the German nationality characters with a German accent, etc. (see the detailed phonetic analysis of their speech peculiarities in Delabastita 2012: 197-205).

\section{Research questions, corpus, methodology}

As dubbing has always been the preferred form of AVT in Hungary, it is but natural that 'Allo! 'Allo! was also released for the Hungarian audience in its dubbed version, on two waves: the first one before the change of regime, in 1987, when the first 8 episodes were created for the Hungarian Television, and the second version was produced between 2001 and 2002, this time the whole series being dubbed for Duna Television. ${ }^{1}$

In the present study, I would like to focus my attention on the broken English speech variety of only one character from the series, namely Officer Crabtree, and the Hungarian dubbed version of his speech, aiming to provide counterevidence to the frequently mentioned claim that linguistic humour in general, and audiovisual humour in particular, is very difficult to render in a target language (cf. Zabalbeascoa 
1996; Chiaro 2000, 2005; Benő 2016; Drahota-Szabó 2016; Camilli 2019). In order to prove this claim, I would like to answer the following research questions:

1. Is it possible to provide a similarly "broken" and, hence, hilariously indecent translation of Crabtree's utterances in the target language?

2. Is it possible to achieve similarly ambiguous utterances with a humorous effect?

3. What kind of transfer operations does the translator employ?

4. If a linguistic blunder is not translated (in its own place), what other possibilities are there for its compensation?

In order to be able to answer the above questions, it is necessary to compare Officer Crabtree's broken English source language utterances and the similarly broken Hungarian target text (found in the dubbed version of the episodes). With this in mind, the following methodology was employed: I have selected, viewed, and transcribed Crabtree's (and, in certain cases, his speaking partners') utterances both from the English and the Hungarian audio soundtrack, creating a corpus of around 6,000 words, comprising 14 episodes from the series, as follows:

Series 2: Episodes 3 (The Policeman Cometh), 4 (Swiftly and with Style), and 5 (The Duel);

Series 3: Episode 3 (The Sausage in the Wardrobe);

Series 4: Episode 5 (The Sausages in the Trousers);

Series 5: Episodes 2 (The Camera in the Potato), 7 (No Hiding Place), 13 (Ribbing the Bonk), 14 (Communists in the Cupboard), 15 (A Duck for Lunch), 16 (The Exploding Bedpan), 17 (Going Like a Bomb), 19 (Puddings Can Go Off)

Series 9: Episode 5 (A Fishy Send-Off)

The broken English utterances, their "good English" variants, and the Hungarian dubbed version were placed into chart with parallel columns for the sake of better comparison. This corpus lies at the basis of the analysis of the translation strategies and translatability problems faced by the translators of the Hungarian version in order to achieve the same humorous effect (see Venuti's Skopos theory). The names of script translators of the selected episodes are Tamás Görgényi, Gábor Kozik, Klára Pető, Kata Csizmás, and Anna Székely.

The paper will be structured accordingly: first, research carried out in the domain of humour translation for the screen is briefly reviewed. This section is followed by the introduction of the concept of dubbing viewed from a linguistic perspective, with a short insight into the Hungarian dubbing tradition and its present-day evolution, while the bulk of the article consists of the translatological comparison of a series of examples taken from Crabtree's garbled English lines and their Hungarian rendition found in the dubbed version. 


\section{Translation of verbal humour for the screen}

In the past two decades, an ever-growing number of research studies has been carried out within the field of audiovisual humour translation. Suffice it to mention the earlier work of Vandaele (1999) on the analysis of audiovisual humour in The Naked Gun and A Fish Called Wanda, Antonini's (2005) and Bucaria's (2007) studies on the perception of subtitled humour in Italy, Chiaro's $(2006,2007)$ huge work, among others, on the analysis of taboo terms in screen translation, or, more recently, the collection of studies edited by Chiaro (2012) on the translation of humour and the media, the studies of Mudriczky (2014) on the dubbed versions of an American cartoon or of Zolczer (2016) on the analysis of humorous scenes and their Hungarian dubbed and subtitled versions of American sitcoms or the collection of essays edited by De Rosa et al. (2014). One of the main ideas to be highlighted in connection with AVT in general, and of audiovisual humour in particular, is that the verbal code is just one component of the four, equally significant elements, and this equilibrium needs to be achieved for a proper translation. Figure 1 below illustrates the necessity for the equality among these elements.

\begin{tabular}{c|c|c|}
\multicolumn{1}{c|}{ Verbal } & \multicolumn{1}{c}{ Audio $\begin{array}{c}\text { Words } \\
\text { heard }\end{array}$} & $\begin{array}{c}\text { Words } \\
\text { read }\end{array}$ \\
\cline { 2 - 3 } Non-verbal & $\begin{array}{c}\text { Music }+ \\
\text { special } \\
\text { effects }\end{array}$ & The picture \\
\cline { 2 - 3 } & Photography \\
\hline
\end{tabular}

Figure 1. The four components of the audiovisual text (Zabalbeascoa 2008: 24)

The present study aims to complete this line of studies carried out from a qualitative perspective. In our analyses, we will focus exclusively on the verbal code out of the above mentioned four components, with the additional claim that the visual element (Crabtree's straight face while pronouncing his words, his serious gestures and body language), in parallel with the bawdy terms included in his speech, is a constant feature that generates laughter. In the analysis of Officer Crabtree's broken English utterances that produce laughter in the audience, we will apply Chiaro's (2006: 200) three strategies for the translation of verbally expressed humour in AVT material:

1. Substituting the verbal humour in the ST with a different type of verbal humour (the latter preserving partially the form or meaning of the original humour, or both);

2. Replacing the verbal humour in the ST with an idiomatic expression in the TL;

3. Replacing untranslatable humour in the ST with compensating humour in the TL in a different part of the TT. 
We find that this classification is useful as it helps to describe the results of the translation, i.e. in our case, the Hungarian dubbed text.

Humour translation is based on theories of humour. For the sake of our analysis, in this study, we will rely on two: superiority and incongruity theories of humour. On the one hand, superiority theories are societal, having to do with ridiculing, aggressing, or disparaging the target or the victim of humour, frequently called the butt of a joke. In this respect, humour contributes to the creation of inclusion (in-groups) or exclusion (out-groups) or hierarchies between persons, between those who understand or do not understand the joke (Vandaele 2010: 148). On the other hand, the incongruity theories of humour are cognition-based and claim that the emergence of humour is usually related to a certain kind of incongruity with the context: the audience is placed in a frame, and the element of surprise in the humorous utterance breaks this frame, leaving the reader/viewer in a state of uncertainty. The moment they regain their superiority, the incongruous situation is resolved, the act of resolution giving way to humorous (perlocutionary) effect.

As Vandaele claims, "the translator of humor has to cope with the fact that the 'rules', 'expectations', 'solutions', and agreements on 'social play' are often groupor culture-specific. Parody, for instance, is only accessible to those who are at least vaguely acquainted with the parodied discourse. Imitations of accents are only imitations for those who know the original" (Vandaele 2010: 149). As Crabtree's distorted words have a strong connotation with taboo language, the viewers of the sitcom comprehend the incongruity of the linguistic situation, which creates a certain tense atmosphere. The moment they are able to decipher the meaning behind the words or phrases, a state of relief occurs, and laughter ensues.

In the analysis of the translation of Crabtree's humorous utterances, I will apply the terms "procedures" or "strategies", as defined by Toury (1995: 55-61), which are prescriptive terms. As my present corpus is fairly limited, the concept of "translation tendency" is also preferred as it is less restrictive (cf. Arampatzis 2015: 69). In translation analysis, the term "equivalence” is employed (in Baker's (2018) terms), referring to lexical, grammatical, textual, and pragmatic equivalence. In the case of situation comedies, translators will place "comic equivalence" as a primary translation procedure. Furthermore, compensation is also to be taken into account in the case of humour translation, mainly "compensation in place [which] makes up for the loss of a particular effect at a certain place in ST by recreating this effect at a different place in TT" (Hervey and Higgins 1992, qtd. in Shuttleworth and Cowie 2013: 25), mainly used for the translation of untranslatable puns (regarding untranslatability, cf. Hermans 2019, Drahota-Szabó 2016, Benő 2016).

Regarding the analysed genre, situation comedy (sitcom) is a dramatic genre broadcast on television. Its main aim is to entertain its audience through visual and verbal humour. "As any other audiovisual text, the situation comedy transmits its message through the convergence of two communication channels (aural and 
visual), where several signifying codes (linguistic, paralinguistic, kinetic, musical, photographic and so on) contribute their bits of information" (Chaume Varela 2004: 15, qtd. in Arampatzis 2015: 70). The visual input is extremely emphatic in Crabtree's case as well: his serious dark uniform of a French gendarme, his facial expressions, gestures, and body language all contribute to the humorous effect he produces in the viewers, the success of the sitcom heavily relying on his character.

\section{Genre and register: Situation comedy and taboo language}

Situation comedies do not normally use ordinary, neutral register, but they heavily rely on lower register, mainly taboo language (Blake 2019), which has great relevance in making audiences laugh (Yus 2016). A taboo word is a word "that many people consider offensive or shocking” (Oxford Learner's Dictionary); a taboo term is considered so offensive or embarrassing that people must not mention it". ${ }^{2}$ Taboo expressions, also called "offensive language" (Hughes 2006), "bad language" (McEnery 2006), “dirty language” (Jay 1992), or "foul language” (Wajnryb 2005), include "sexual and scatological obscenities, ethnic-racial slurs, insults, namecalling, profanity, blasphemy, slang, jargon and vulgarities of all kinds, including the forbidden words of non-standard grammar" (Allan and Burrington 2004: 250). The word refers to what is prohibited by social, cultural, or religious mores.

The translation of taboo terms in AVT involves several strategies, ranging from 1. censoring the taboo, 2. substitution of the taboo, or 3. taboo for taboo to 4. euphemism, i.e. substitution in an agreeable or inoffensive way. In our case, censoring the taboo is not applicable as the taboo term used in Crabtree's language (i.e. decent terms distorted into indecent ones) is itself the source of humour. Therefore, translation strategies 2-4 can be noticed in the translations to be analysed (see Section 5). The presence of taboo terms is an organic element of the character's humorous manifestations; therefore, their replacement with equivalent or similar taboo words in the TT is essential in order to achieve a similar effect in the target audience (Ávila-Cabrera 2015, 2016).

In terms of official and unofficial translation of audiovisual products (in our case, films), it can be stated, based on previous research (see, for instance, Beseghi 2015), that professional translators tend to remove, more or less consciously, the "disturbing" elements from the ST, while fansubbers have the tendency to stick to the ST, not only regarding its linguistic content but its register and style as well. There is a certain kind of (self-)censorship on the part of the (official) dubbing translators that governs their attitude and the translating process, while subtitlers (especially fansubbers) tend to use taboo terms more freely in their translations, probably in order to meet their viewers' expectations.

2 https://www.oxfordlearnersdictionaries.com/definition/english/taboo_1?q=taboo 


\section{Dubbing as a form of audiovisual translation}

While subtitling is defined as an interlingual form of AVT, where the original soundtrack remains audible while the translated verbal message is added to the product, in the form of written text presented on the screen in synchrony with the original soundtrack (Gottlieb 2001a: 87; 2001b: 15), dubbing “does not normally add another component to the multimodal product, but rather replaces one” (Valdeón 2018: 112). In dubbing, the original speech is replaced by the target-language voice track, "which attempts to follow as closely as possible the timing, phrasing and lipmovement of the original dialogue" (Luyken et al. 1991: 31). " "The goal of dubbing is to make the target dialogues look as if they are being uttered by the original actors so that viewers' enjoyment of foreign products will be enhanced" (Chiaro 2009: 144). As the corpus under discussion is part of the Hungarian dubbing tradition, it is worth gaining a deeper understanding of its development over the decades.

\subsection{A brief history of Hungarian dubbing}

Hungary is one of those European countries where dubbing has a long tradition. Its history goes back to the mid-1930s, when - following the German and Italian model of the time - governmental decision was taken to present foreign films with Hungarian voices. Accordingly, in November 1935, the first film dubbed into Hungarian, entitled Viereinhalb Muskitiere [Four and a Half Musketeers] was released.

After a break of a decade, when original Hungarian film production took over the market, a new wave of Hungarian dubbing was started. The country having fallen behind the Iron Curtain, Soviet films were presented first in dubbed Hungarian version as the regime realized that foreign films propagating communist ideas could also become excellent means to manipulate public consciousness. Beginning with the 1950s, an increasing number of dubbed films was released, works of Magyar Szinkronfilmgyártó Vállalat [Hungarian Dubbed Film Production Company], later called Pannónia Filmsúdió [Pannonia Film Studio], the first independent studio dealing exclusively with dubbing.

Beginning with 1963, the state ordained that each foreign film presented on television was also to be aired in its Hungarian dubbed version. By then, Hungarian dubbing had become a form of art, having gained world-famous recognition. Films were dubbed by the best professionals, both script translators and dubbing actors. Regarding the translation of scripts, suffice it to mention the iconic dubbed version of the American animated series The Flintstones (1960-1966), in Hungarian entitled Frédi és Béni, avagy a két kókorszaki szaki [lit. Fred and Barney, or the

3 For further definitions and descriptions of dubbing cf., for instance, Chaume 2006, 2013; Chiaro 2009; Bogucki 2013; Ranzato 2016. 
two pros from the Stone Age], the work of script translator József Romhányi (also nicknamed 'Rímhányó', i.e. 'rhyme heaper') with its dialogues full of puns and general linguistic virtuosity, far more creative than the original source text. "He turned the original's prose into a complex flow of snappy and tongue-in-cheek poetry, creating a verbal tapestry of inventive and intellectual humour absent from the original" (Martonfi-Havas 2019). Having no room for a more detailed presentation, we illustrate Romhányi's verbal playfulness with examples of titles and two-liners from the Hungarian dubbed version, together with their possible English back-translation: ${ }^{4}$

Table 1. Examples of Romhányi's rhymed dubbing

\begin{tabular}{ll}
\hline Titles & Back-translation \\
\hline Lokál-vokál kan-dúrban & nightclub-vocal in male-major/tom-cat \\
\hline Lóvátétel & $\begin{array}{l}\text { bamboozling/beguiling (ref. to } \\
\text { "jóvátétel” - redeeming) }\end{array}$ \\
\hline $\begin{array}{l}\text { Azért kezdtem a testem kisportolni / } \\
\text { hogy legyen mit a nők közt kisorsolni. }\end{array}$ & $\begin{array}{l}\text { I have started to have an athletic figure } \\
\text { / so that women can win it. }\end{array}$ \\
\hline $\begin{array}{l}\text { Nézzük, hogy az uszodát / milyen } \\
\text { hamar úszod át! }\end{array}$ & $\begin{array}{l}\text { Let's see the swimming pool / how fast } \\
\text { can you swim through it? }\end{array}$ \\
\hline
\end{tabular}

The line of excellently dubbed foreign films could be continued with the American soap opera Dallas (1978-1991), aired in Hungary between 1990 and 1997 by the Hungarian Television. These were the heydays of Hungarian dubbing, characterized by the translators' inventiveness, masterly creativity, and artistic freedom.

By the 1980s, dubbing had become an organic part of foreign films marketing in Hungary. As at the time dubbing was considered a form of art and not a branch of film-making industry, it had its own specialized journals: first, Pannónia Filmhíradó (Pannonia Newsreel), published between 1981 and 1986, followed by Szinkronika (Synchronicle) $^{5}$ (1987-1991).

The change of regime in 1989 brought about radical changes not only in the Hungarian film-making but also in the history of dubbing due to the rapidly growing number of commercial television channels and the development of video renting culture. The monopoly of the Hungarian Television, the main producer of film dubbing, was overthrown by the emergence of several new dubbing studios. Television channels were forced to make their own cheap versions of dubbed soundtracks, resulting in a constant degrading of the dubbed quality (for instance,

4 https://www.origo.hu/teve/20200604-fredi-es-beni-avagy-egy-legendas-forditas-nyomaban2020.html. https://cooltour.reblog.hu/amig-tart-a-kokorszak-legyen-mindig-loporszag--romhanyi-jozsef. Romhányi would be 100 years old in 2021.

5 The title itself can be identified as a pun, a linguistic blending of szinkron+krónika (synchrony+chronicle). 
the 1993 VHS edition of The Return of the Jedi, where the ST "lightsabre” is rendered as "fényszablya" instead of "fénykard" or where the term "droid" is translated as "android"). ${ }^{6}$ Despite the fact that at present there is a relatively low number of high-quality translations that Hungarian audiences can enjoy, there is still hope that high-quality dubbing will prevail in the future (Tóth 2015, Martonfi-Havas 2019).

More recent successes of contemporary dubbing script writers include Dávid Speier $^{7}$ (the Paganini of Hungarian dubbing translation) ${ }^{8}$ or Eszter Pataricza, ${ }^{9}$ just to name two of the most prolific and creative artists.

\section{Officer Crabtree speaking in "Fronch" [broken English] - General features}

Officer Crabtree appears on the scene of 'Allo! 'Allo! in the $11^{\text {th }}$ episode of the $2^{\text {nd }}$ season. According to the plot, as a trained spy who speaks perfect French, he is parachuted in occupied France near the village of Nouvion. He is a true Englishman, ${ }^{10}$ a spy disguised as a French policeman, and his main mission is to serve his country as a true patriot, also keeping contact with the members of the French Resistance.

As the source soundtrack reveals it, his first utterances are high-standard English, with an upper-class English pronunciation. However, the moment he addresses his words to the French villagers, he starts to speak a special, idiosyncratic English that makes him unique and humorous at the same time. Soon he is referred to as "the stupid Englishman disguised as a policeman" or as "the stupid Englishman who thinks he can speak French". "He believes that the French he learnt at the military academy suffices by way of linguistic camouflage to allow him to blend in with the locals" (Delabastita 2012: 203). His "French" is so mangled and incomprehensible at times that it is the Resistance member Michelle who "translates" his words for his interlocutors.

6 https://www.origo.hu/filmklub/20151223-darth-vadernek-tudotagulasa-lehetett-kosztola-tiborinterju-star-wars-schery-andras.html

7 Among the best dubbing works of Dávid Speier: The Darkest Hour (2017), Knocked up (2007) with the Hungarian title Felpattintva, Forgetting Sarah Marshall (2008) with a parallel Hungarian title Lepattintva, Out of Sight (Mint a kámfor, 1998), For Richer or Poorer (Szegény embert az Amish húzza, 1997), or Asterix and Cleopatra (Asterix és Obelix - A Kleopátra küldetés), with its brilliant translation in verse.

8 Marossy 2018 - https://wmn.hu/kult/49491-agyjelenet-cigireklam-es-a-magyar-rim-unnepekokorszaki-modra-avagy-boldog-szuletesnapot-fredi-es-beni

$9 \quad$ Eszter Pataricza created the Hungarian dubbed version of The Lord of the Rings series (20012003), of the blockbusters You've Got Mail (A szerelem hálójáb@n (sic!), 1998), Skyfall (2012), Nine Months (Áldatlan állapotban - Ugye szólsz, ha szülsz!, 1995), The Bridges of Madison County (A szív hídjai, 1995), Titanic (1997), or Good Morning, Vietnam! (1987).

10 Even his name is very English. "Crabtree" is a name of Anglo-Saxon origin, a topographical for one who dwelled by a wild apple tree. The name derives from the Middle Ages, from the Old English pre- $7^{\text {th }}$ century "crabba-treow", crabba meaning "apple”. 
Crabtree's "language supposedly spoken in 'reality' (represented language) is different from the language actually spoken on the soundtrack (representing language)" (Delabastita 2012: 206), i.e. his "French" is actually broken English on the soundtrack. This English speech contains traces of French pronunciation to suggest that he is actually speaking French in the fictional world of the series. It is "the slow, careful and emphatic manner [of speech] of someone who wants to make sure that he will be understood in what is for him a foreign tongue" (Delabastita 2012: 204). He does not make too many grammatical errors, and his sentences are more or less correctly formed both morphologically and syntactically. The most striking feature of his speech is of phonological nature: one can detect a systematic substitution of sounds (vowels especially) causing the speaker's intended meaning to go behind "a totally bizarre utterance that is either absurd or bawdy, or both" (Delabastita 2012: 204), e.g. "loosence" ['lu:səns] instead of "licence" ['lassəns] or "wee [wi:] instead of "way" [wei]. As the above two examples show, the most frequent phonetic change is the vowel change, and the mispronounced words have either a nonsensical or a sexual or scatological connotation, and the humorous effect is induced by the displacement of the expected frame in the cognitive expectation of the audience. Mispronunciations in Crabtree's utterances are more or less constant and predictable, in general terms. However, they can be classified according to whether they are recurrent mispronunciations or new errors. An example of the former is his famous catchphrase "Good moaning!" uttered at any time of the day, which stands for the usual English greeting "Good morning!" As to the latter ones, they can be totally new, original "errors", which leave the audience surprised, evoking a strong humorous effect.

\section{Crabtree dubbed in Hungarian}

When translating (dubbing) Crabtree's broken English utterances into Hungarian, the translators followed certain procedures. First, they attempted to translate the character's intended meaning (illocutionary forces) faithfully. Secondly, they tried to follow the phonetic changes in the source text by similar vowel (and sometimes consonant) substitutions in the target text, creating similarly absurd or humorously indecent words. Thirdly, they were also constrained by the canned laughter signals in the source soundtrack; therefore, the verbal jokes in the dubbed version were to be uttered in synchrony with the ones in the English text, possibly on the same spot.

Accordingly, certain general and more specific strategies and operations can be noticed in the dubbing translation. One such general feature is the frequent use of the French accent, characterized by nasal vowels, the elision of the word initial $h$ sound (which is a semi-vowel in French, and therefore not pronounced), and the use of the uvular $s$ in the Hungarian spoken text (for more details, see Section 6.1 below). In most of the cases, the French accent is employed in order to compensate for the 
lost meaning of the ST broken utterance. Another general feature is adaptation and compensation. Adaptation, used in its Skopos theoretical sense, refers to a strategy employed by the translator to make the ST suitable for the expectations of the TT audience, also referred to as "situational equivalence" (Vinay-Darbelnet 1995: 39, Fawcett 1997: 39), "as it works by replacing ST elements by TL items which in some way serve the same function and are thus 'equivalent"' (Shuttleworth-Cowie 2013: 4). Compensation, on the other hand, is a technique used to "make up for the translation loss of important ST features by approximating their effects in the TT through means other than those used in the ST" (Shuttleworth-Cowie 2013: 25).

Among the more specific strategies, the corpus showed the use of substitution and omission as well. Substitution here is referred to as vowel substitution in order to distort proper Hungarian words and create indecent ones, similar to the ST. The strategy of omission is employed whenever "a particular item or expression is not vital enough to the development of the text” (Baker 2018: 43).

As mentioned above, the most frequent feature of Crabtree's speech is the substitution of vowel sounds in such a way as to create humorous effect. The mixing of sounds usually leads to malapropism (i.e. the habitual misuse of similar sounding words, especially with humorous effect) ${ }^{11}$ or to double entendre (i.e. words or phrases meant to be taken with double meaning: one meaning being obvious, literal, or innocent, the other meaning usually taboo or having a sexual subtext), ${ }^{12}$ both of which could be interpreted as wordplays or puns. Due to the differing structure of source and target language, translating wordplay can be a challenging task: "whatever its exact form or function, wordplay exploits the intrinsic structure of the (source) language used and throws into prominence certain characteristics of that language for which it may well be difficult or impossible to find analogues or equivalents in the target language" (Delabastita 2004: 600).

In the following section, first (i) I will discuss the dubbing of the recurrent elements in Crabtree's utterances, and then (ii) I will proceed to the translation of fixed expressions and idioms (Dore 2020), based on the selected episodes.

\subsection{Recurrent elements and their translation}

\subsubsection{Recurrent elements with neutral or low register connotation}

As mentioned above, one of the most striking recurrent phrases that leaves Crabtree's mouth is "Good moaning!". Due to the fact that the phrase is a play on words, the Hungarian script translators also resorted to using a mispronounced version of

11 https://psychology.wikia.org/wiki/Malapropism

12 https://literaryterms.net/double-entendre/. Double entendre is also examined by Arthur Bostrom himself, the actor who played the role of Crabtree in Allo! Allo! in a BBC programme in 2014: https://www.bbc.co.uk/sounds/play/b04f9r9k. 
the word reggel [morning] by introducing an extra vowel, thus resulting in a new Hungarian word, reggeli [breakfast]. As the series developed, several other solutions were found: Jó reggelt! (S2E4/P12), ${ }^{13}$ Jó reggelit! (S5E13/P39), or the combination of the two, the most frequently used Jó reggelit! (S5E19/P45). ${ }^{14}$ In the original soundtrack, one can often notice Crabtree pronouncing English words containing a guttural fricative "r" as a sign of his spoken French. A similar voiced uvular sound can be heard in the Hungarian dubbed version as well, instead of the rolled " $r$ " sound, adding an extra humorous effect to the character's verbal manifestation.

Further recurrent elements include words that are related to the everyday life of the French gendarme, walking in the streets of Nouvion, passing by Renés café, bringing news to him and/or to the girls from the Resistance. In this way, the following renditions can be detected in the dubbed version:

Table 2. Recurrent elements: neutral/low register

\begin{tabular}{|c|c|c|}
\hline Mispronounced language & Meaning & Hungarian version \\
\hline René [вєnе] & René & Rönó [вӧnó] \\
\hline Ronnie & René & Rönó [вönó]/ Röné \\
\hline $\begin{array}{l}\text { I have good nose! (S2E4/ } \\
\text { P12) }\end{array}$ & I have good news! & Jól van orrom. \\
\hline $\begin{array}{l}\text { I have for you good nose. } \\
\text { René: What is your nose? } \\
\text { (S5E2/P/28) }\end{array}$ & $\begin{array}{l}\text { I have for you good news! } \\
\text { What is your news? }\end{array}$ & $\begin{array}{l}\text { Jó hú } \text { 'om van magának. } \\
R: \text { a, pengesse meg. }\end{array}$ \\
\hline $\begin{array}{l}\text { I have bad nose! } \\
\text { (S5E14/ P40) }\end{array}$ & I have bad news! & $\begin{array}{l}\text { Rossz íreket hoztam } \\
\text { Önnek. }\end{array}$ \\
\hline $\begin{array}{l}\text { I wish to give you a } \\
\text { massage. (S5E17/P43) }\end{array}$ & $\begin{array}{l}\text { I wish to give you a } \\
\text { message. }\end{array}$ & Új íreket hoztam Önnek. \\
\hline $\begin{array}{l}\text { I have brong crootins } \\
\text { from Brutish Intolligence } \\
\text { Headquitters. (S2E3/P11) }\end{array}$ & $\begin{array}{l}\text { I have brought greetings } \\
\text { from British Intelligence } \\
\text { Headquarters. }\end{array}$ & $\begin{array}{l}\text { Én hoztam üdvözleteket } \\
\text { britis intelligens szervíz. }\end{array}$ \\
\hline $\begin{array}{l}\text { British Intolligance } \\
\text { (S5E17/P43) }\end{array}$ & British Intelligence & titkos szaglászat \\
\hline $\begin{array}{l}\text { I give them a quick curse } \\
\text { in the French longwatch. } \\
\text { (S2E5/P13) }\end{array}$ & $\begin{array}{l}\text { I gave them a quick } \\
\text { course in the French } \\
\text { language. }\end{array}$ & $\begin{array}{l}\text { Ó, én adtam nekik gyors } \\
\text { talpalávalót francia } \\
\text { nyelvböl. }\end{array}$ \\
\hline
\end{tabular}

As it can be seen in Table 2 above, the dubbing translators resorted to different strategies when rendering these paronymic words into Hungarian. On the dubbed soundtrack, René's name is pronounced either with its proper French pronunciation

13 The phonetic mark в stands for the voiced uvular fricative, typical, for instance, in Parisian French, or in most parts of Germany.

14 The abbreviations refer to the number of series (S), the number of episodes (E), and the number of the Hungarian dubbed parts (P). 
[röné] or [вöné], with either an alveolar or a uvular "r" or imitating the name of the French car "Renault" [röno], all eliciting audience laughter.

The phrase I have good nose! has been translated with different strategies. Instead the possible Jó orrom van, which would be a literal translation of the ST, the translator opted for compensation via an ungrammatical utterance Jól van orrom. [lit. well is my nose], where the mispronunciation - actually a distorted but intelligible utterance - is substituted by a grammatically and syntactically incorrectly formed sentence. I consider that this solution cannot achieve the same comic effect as the ST utterance. The other occurrence of good nose is rendered by the replacement of hírem [my news] by the paronymic húrom [my string] pronounced with the uvular в. As René is also joining in with the mispronunciation, the verbal game is carried on in his line as well: $N a$, pengesse meg [well, play it/ strum it], where functional equivalence is achieved, resulting in a similar TT meaning (i.e. tell me your news). Nose (meaning "news") is also rendered in Hungarian by another interesting solution: ísek [Irish], which may be interpreted as a result of the mispronunciation of the Hungarian hírek with a French accent by the elision of the word-initial " $h$ " letter/sound. However, deleting the word-initial "h" leads to the pronunciation of another meaningful word, meaning "Irish".

Along the same line of thought, the ST I wish to give you a massage (meaning: message) is similarly rendered with the Hungarian Új íreket hoztam Önnek [lit. I have brought you new Irish(wo)men], which signals that the translators were focusing on the illocutionary force of the utterance. Although the ST utterance is completely different from the previous one (cf. I have good nose! vs. I wish to give you a massage), the TT solution is almost identical (rossz íreket vs. új íreket) despite the slightly indecent connotation of the second ST message.

Similar humorous vowel changes can be detected in the name of the institution Crabtree works for. He pronounces it as Brutish Intolligence Headquitters, the name containing words with negative connotations, incongruous with the mission of the British Intelligence Headquarters. The adjective brute means "savagely violent animal as opposed to human being"; the verb toll has the slang meaning of "to harm or damage somebody/something, esp. in a gradual way"; the verb quit means "to leave a place permanently". In order to render the jumbled name of this prestigious British institution in Hungarian, the translators resorted to two different solutions. In S2E3/P11, they came up with britis intelligens szervíz [British intelligent service], i.e. an almost literal translation of the source language variant, where the noun szervíz [garage] reflects on the small workshop-like nature of the institution. This phrase is included into a grammatically and syntactically incorrect Hungarian sentence: Én hoztam üdvözleteket britis inteligens szervíztól, containing the redundant presence of the first person singular pronoun én [I] in spite of the fact that the Hungarian predicate hoztam [I have brought] contains the personal pronoun marker at the end of the verb; the use of a plural direct object (instead of 
a singular one) - all this in a wrong word order. In this way, Crabtree's Hungarian sentence does not contain as many negative connotation words as the ST; however, it is similarly incomprehensible to the French villagers. Therefore, it is Michelle (of the Resistance) who has to "mediate" between them, uttering the sentence in plain language: a brit hírszerzố központból üdvözletüket küldik [they send greetings from the British Intelligence Headquarters]. Later in the series (S5E17/P43), another Hungarian translation variant can be found for the mispronounced name of the office: titkos szaglászat [secret snooping], meaning titkos szolgálat [secret service]. This solution seems to be a better option as, on the one hand, it has the same number of syllables with a different sound variation, and, on the other hand, it refers to the actual mission of the institution, i.e. to sniff around, to work undercover to collect human intelligence in support of national security.

As a final example in this section, quick curse in the French longwatch [i.e. quick course in the French language] contains a malapropism: the profane curse standing for course, completed with the mispronunciation of language, resulting in another (meaningful) compound word: longwatch. Again, the Hungarian translation of the utterance does not contain such low-register lexemes as the ST but rather an analogue phrase transformation: gyors talpalávaló (lit. quick music for under their soles], where the compound talpalávaló usually has a slightly humorous connotation in Hungarian, and it means "stimulating, fast-paced music, esp. for Hungarian csárdás dancing”. The phrase gyors talpalávaló actually stands for gyorstalpaló [a quickie, a crash course]. Similar to the previous examples, here, as well, one or two extra syllables are added to the original word(s) to make new, meaningful lexical units (here: gyorstalpaló changed into gyors talpalávaló), the humorous effect retained in spite of the lack of negative connotation.

\subsubsection{Recurrent elements with taboo connotation}

So far, it could be noticed that the ST mangled words have a neutral or slightly lowregister meaning, the TT equivalents having similarly neutral or even higher-register overtone. However, more often than not, bawdy, indecent humour is associated with Crabtree's utterances. The "French" gendarme mangles his words in such a way that they will contain syllables that deflect the word's original sense, resulting either in nonsense or in slang taboo words, having sexual or scatological connotations. Here is a list of the most frequently used ones: wee [way], lick [luck], piss [pass], bums [bombs], bummer [bomber], loo [law], dick [thick]. ${ }^{15}$ The Hungarian dubbed variants are equally slangish, or they contain newly coined lexemes, as shown in Table 3 below:

15 In square brackets, the meaning of the mispronounced word is given. 
Table 3. Recurrent elements with taboo connotation

\begin{tabular}{|c|c|c|}
\hline Mispronounced language & Meaning & Hungarian version \\
\hline $\begin{array}{l}\text { You cannot spoke like } \\
\text { thos to an ifficer of the } \\
\text { loo! } \\
\text { (S5E15/P 41) }\end{array}$ & $\begin{array}{l}\text { You cannot speak like this } \\
\text { to an officer of the law! }\end{array}$ & $\begin{array}{l}\text { Nahát, micsada dolog! } \\
\text { Mért kell ilyen dовván } \\
\text { beszólni? }\end{array}$ \\
\hline $\begin{array}{l}\text { I shall lick you up for } \\
\text { disturbing the piss. } \\
\text { (S5E7/P 33) }\end{array}$ & $\begin{array}{l}\text { I shall lock you up for } \\
\text { disturbing the peace. }\end{array}$ & $\begin{array}{l}\text { Megbüntetem } \\
\text { csendöвhábовításéвt. }\end{array}$ \\
\hline $\begin{array}{l}\text { She has been pissing } \\
\text { fudged bank notes in the } \\
\text { hit shop. (S3E3/P17) }\end{array}$ & $\begin{array}{l}\text { She has been passing } \\
\text { forged bank notes in the } \\
\text { hat shop. }\end{array}$ & $\begin{array}{l}\text { Hamus bunkjeggyel } \\
\text { fizetőzött a kalpagosnál. }\end{array}$ \\
\hline $\begin{array}{l}\text { There are pissers all over } \\
\text { the track. (S2E } 4 / \mathrm{P} 12)\end{array}$ & $\begin{array}{l}\text { There are pieces all over } \\
\text { the track. }\end{array}$ & $\begin{array}{l}\text {... és a kolbász szintén } \\
\text { jégbe ment. }\end{array}$ \\
\hline $\begin{array}{l}\text { The money you nicked } \\
\text { was the property of the } \\
\text { Gestopoo. (S5E14/P40) }\end{array}$ & $\begin{array}{l}\text { The money you nicked } \\
\text { was the property of the } \\
\text { Gestapo. }\end{array}$ & $\begin{array}{l}\text { A pénz, amit megfújtak, a } \\
\text { Gespopó tulajdona volt. }\end{array}$ \\
\hline
\end{tabular}

Crabtree frequently defines his position as officer of the loo [officer of the law], where loo is the slang word for toilet. The strong contradiction between the meaning of the paronymically contrasted law and loo leads to humorous effect. The Hungarian dubbing translators resorted to substitution of the slang word with two separate clauses, with a reprimanding tone, thus achieving the same illocutionary force as the ST sentences but with a totally different form. The pronunciation of the sentences also suggests Crabtree's broken French rendered by a similarly broken Hungarian micsada dolog [what a thing]; Mért kell ilyen doвván beszólni? [why does one have to speak so harshly], also employing the Hungarian slang beszólni (to insult, to taunt), also employing the uvular $r$, which has an aristocratic connotation. ${ }^{16}$

The verb piss may appear either as the distortion of pass or piece or even peace - as the above examples illustrate. The Hungarian translations are of much higher register: they contain a play on words by adding an extra syllable in order to create a new word, which thus creates a totally new meaning. The phrase disturbing the piss [meaning: disturbing the peace] rendered in Hungarian as megbüntetem сsendöshábовításést [lit. I will fine you for disturbing the gendarme] is a humorous re-creation of the word csendháborítás [disturbing the peace], with its paronym csendör [gendarme] to be interpreted as a reference to Crabtree himself.

The taboo term piss can also mean piece in other examples. The context of this example is that the painting of the "Fallen Madonna with the Big Boobies" (the running gag in the series) was hidden in a substantial sausage and sent to Berlin by

16 Hungarian aristocrats frequently had a special pronunciation feature of burring (using the uvular $r$ sound non-existent in Hungarian), which was due to the fact that as children their first language was German or French, these languages having the uvular $r$. 
train. However, the train was bombed by the Royal Air Force, and it is believed that the portrait was also destroyed: There are pissers all over the track meaning "There are pieces [of it] all over the track." The dubbing translators resorted to an ingenious solution. Instead of looking for a similar taboo word in the TT, the Hungarian version contains the mispronounced idiomatic phrase és a kolbász szintén jégbe ment [and the sausage also went to ice], having a much more elevated register than the ST, meaning égbe ment [went to heaven], while the illocutionary force of the utterance was retained (the sausage was blown up), maintaining the humorous effect.

One of the most creative solutions for the translation of taboo words is the rendering of Gestapoo (in Hungarian Gespopó), where the last syllable of the English word is the taboo term, while the last two syllables of the Hungarian word has similar meaning, i.e. a slang for back side, bottom.

A similarly inventive rendering of the English taboo slang word dick can be found in Table 4 below.

Table 4. Novel elements with taboo connotation I

\begin{tabular}{lll}
\hline Mispronounced language & Meaning & Hungarian version \\
\hline The bums will be loaded & The bombs will be loaded & A bambát bedugjuk \\
on a bummer on a dick & on a bomber on a thick & a két bombázóval az \\
night and then they will & night and then they will & éj lepedójén és aztán \\
be dripped over Ongland. & be dropped over England. & elszállnak az anglikán. \\
(S5E17/P43) & & \\
\hline
\end{tabular}

In the Hungarian version, through a vowel change similar to the ST, the word bomba is replaced by bamba [stupid, oafish, tomfool]. The lexeme bombázó is ambiguous in Hungarian as well, referring to 1. an aircraft designed to carry and drop bombs and 2. a pretty woman, lit. translated from Hungarian as "bomb woman" [bombázó]. Moreover, the taboo slang dick in dick night (standing for "thick night”) has been transformed in Hungarian with the paronymic az éj lepedójén [on the sheet of the night] instead of the phrase az éj leple alatt [under the veil of the night]. Finally, the ST they will be dripped over Ongland (meaning, "they will be dropped over England”] is rendered as elszállnak az anglikán [lit. they will fly away the Anglican], which, on a lexical level, is a nonsense. However, as pronounced by the dubbing actor, the lexeme anglikán is separated into syllables, where the Hungarian lik is a vernacular for hole, having a taboo meaning, thus creating a new pun with a similarly indecent meaning as the ST.

As the series advances, more and more creative solutions have been found by the dubbing translators. The background situation in the following example is that the English pilots need new parachutes, but there is no silk available. It is Crabtree who comes up with the idea that the French girls' underwear should be used as an excellent material. 
Table 5. Novel elements with taboo connotation II

\begin{tabular}{|c|c|c|}
\hline Mispronounced language & Meaning & Hungarian version \\
\hline $\begin{array}{l}\text { Crabtree: You must go } \\
\text { and get your hands on the } \\
\text { girls' knockers. }\end{array}$ & $\begin{array}{l}\text { You must go and get } \\
\text { your hands on the girls' } \\
\text { knickers. }\end{array}$ & $\begin{array}{l}\text { C: Rá kell tenni a kezet a } \\
\text { lányok bigyójára. }\end{array}$ \\
\hline $\begin{array}{l}\text { Michelle: He means silk } \\
\text { knickers. } \\
\text { Crabtree: Sorry, perhaps }\end{array}$ & He means silk knickers. & $\begin{array}{l}\text { M: A selyembugyikra } \\
\text { gondolt. } \\
\text { C: Á, pardon, az ákszan }\end{array}$ \\
\hline $\begin{array}{l}\text { my French cod be butter. } \\
\text { (...) (S2E4/P12) }\end{array}$ & $\begin{array}{l}\text { Sorry, perhaps my French } \\
\text { could be better. }\end{array}$ & lehet talán jobb is. \\
\hline
\end{tabular}

Here, the ST goes deeper into the taboo register as knockers is a malapropism for knickers and is the English slang word for breasts. This taboo meaning is creatively transferred in the Hungarian TT as well, preserving the vowel changes and resulting in the same meaning combination. This verbal exchange is one of those rare cases when Crabtree apologizes for his mispronunciation - obviously, with a similarly disfigured phrase, but with exquisite English politeness strategy (see the apologetic sorry and the employment of the hedge perhaps). This polite intention is also rendered in the Hungarian version, where the apology is expressed by pardon [I beg your pardon] and ákszan [accent] derived from French and pronounced with a French accent, alluding to the speaker's "fake" identity and thus eliciting laughter in the audience.

There is a very small number of examples in the corpus where the TT has been translated containing taboo or slang words where there is no such element in the ST. An example is the following, where, according to the context, Crabtree brings the news that René and his companions were seen robbing the bank, and their pictures (poctures) drawn by the witness are already at the station but not yet pinned on the notice board.

Table 6. Novel elements with taboo connotation III

\begin{tabular}{|c|c|c|}
\hline Mispronounced language & Meaning & Hungarian version \\
\hline $\begin{array}{l}\text { Crabtree: Nobody has soon } \\
\text { them because I have not } \\
\text { yet pinned them on the } \\
\text { beard. } \\
\text { René: The beard? } \\
\text { Crabtree: The beard outside } \\
\text { the poloos stootion. } \\
\text { Yvette: He means the board } \\
\text { outside the police station. } \\
\text { (S5E14/P40) }\end{array}$ & $\begin{array}{l}\text { C: Nobody has seen } \\
\text { them because I have not } \\
\text { yet pinned them on the } \\
\text { board. } \\
\text { R: The beard? } \\
\text { Crabtree: The board } \\
\text { outside the police station. } \\
\text { Y: He means the board } \\
\text { outside the police station. }\end{array}$ & $\begin{array}{l}\text { C: Még nem lótte senki, } \\
\text { mert még nem tűztem ki } \\
\text { a rendőrseggre. } \\
\text { R: Milyen seggre? } \\
\text { C: Hát a táblázatra, a } \\
\text { rendórseggre. } \\
\text { Y: Azt akarja mondani, } \\
\text { hogy a rendórségi } \\
\text { hirdetótáblára. }\end{array}$ \\
\hline
\end{tabular}


While in the English ST the neutral term beard is used for board, the Hungarian TT compensates for the later occurrence of the mispronounced police station (poloos stootion) by using its Hungarian equivalent in its similarly wrongly pronounced form: rendörseggre [lit. on a policeman's ass] instead of rendörségre [lit. to the police]. The taboo term is "hidden" in the mispronunciation, which is emphasized even more by René's question for clarification, Milyen seggre? [lit. on what kind of ass?]. Yvette, as usual, mediates between the two speakers, explaining the meaning of the broken sentence.

\subsection{Fixed expressions and idioms}

Officer Crabtree's verbal manifestations contain several fixed expressions and idioms as well. Their dubbed Hungarian versions show a similarly colourful picture. Following Veisbergs (1996: 164-171) and Delabastita's (2004: 604) classification, it can be stated that the fixed expressions and idioms are not maintained in their original form in the ST but are replaced, most frequently with vowel or consonant changes.

Table 7. Fixed expressions and idioms I

\begin{tabular}{lll}
\hline Mispronounced language & Meaning & Hungarian version \\
\hline I have disgeezd as & I am disguised as & Én álöltözetet öltöttem, \\
polooseman so I am & policeman so I am able & mint csendör ahcélból, \\
oble to move aboot with & to move about with & hogy komplett \\
complete frodom. (S2E3/ & complete freedom. & $\begin{array}{l}\text { szabadsággal } \\
\text { P11) }\end{array}$ \\
\hline
\end{tabular}

The ST contains the fixed expression disgeezd as polooseman where Crabtree's vowel changes result in nonsense words (meaning "disguised as policeman"). The Hungarian translators resorted to the employment of semantically correct words, although formulated in an obsolete Hungarian: álöltözetet ölt [put on false clothing]. Here the humorous effect is created by (1) the repetition of the cognate ölt [put on]; (2) the pronunciation of ahcélból [lit. with the purpose/made of steel], pronounced with the uvular в; (3) the phrase komplett szabadsággal [lit. with complete freedom], containing a foreign lexeme. All these elements create the air of aristocratic foreignness and contribute to the creation of Crabtree's character as a foreigner among the French for the Hungarian audience as well.

In the same episode, a foreigner's superiority is further emphasized by another utterance. 
Table 8. Fixed expressions and idioms II

\begin{tabular}{lll}
\hline Mispronounced language & Meaning & Hungarian version \\
\hline In London we are not & In London we are not & Londonban mi nem \\
steeped. We know every & stupid. We know every & vagyunk sztupid. Tudjuk \\
mauve you moke. (S2E3/ & move you make. & minden lépésedról. \\
P11) & & \\
\hline
\end{tabular}

In the Hungarian TT, Crabtree's foreignness is betrayed by the ungrammaticality of his utterance: the redundancy of the $1^{\text {st }}$ person plural pronoun $\mathrm{mi}$ [we] and the direct transfer of the ST stupid, further carried on by the incorrect accusative conjugation of the verb: tudjuk instead of the correct nominative conjugation tudunk.

The line can be continued by an example where it is the dubbing translator who shows his/her ingenuity by creating a new fixed phrase in a place where there is no such element in the ST:

Table 9. Fixed expressions and idioms III

\begin{tabular}{lll}
\hline Mispronounced language & Meaning & Hungarian version \\
\hline I did nit know that it [the & I did not know that it & Én nem tudakoltam, hogy \\
tank] had been droven by & had been driven by René, & azon a harcoskocsin \\
René, René, who walks in & René, who works in the & René utazik, René, aki \\
the beer. (S2E4/P12) & bar. & máskor sörben utazik. \\
\hline
\end{tabular}

On the one hand, the slightly obsolete verb tudakoltam [I enquired] is used instead of its cognate tudtam [I knew], as a paronymic substitution; on the other hand, harckocsi [tank] is replaced by the non-existent harcoskocsi [lit. warrior car]. The phrase who works in the bar is ingeniously translated as sörben utazik [lit. travels in beer], where the Hungarian idiomatic phrase vmiben utazik means “deals with sg.", “is an agent of sg.”, "trades with sg.”. The phonetic change in the ST (walks vs. works) is compensated by a merge of the literal and metaphorical meanings of utazik valamiben, the two meanings being connected by the adverb máskor [another time], which specifies the different "types" of travelling.

Continuing the line of idiomatic expressions and their Hungarian translation, the following example offers the case of a similar vowel change as in the ST.

Table 10. Fixed expressions and idioms IV

\begin{tabular}{|c|c|c|}
\hline Mispronounced language & Meaning & Hungarian version \\
\hline $\begin{array}{l}\text { Good moaning. I am } \\
\text { existed. Any chance of a } \\
\text { cup of kifi? (S5E } 2 / \mathrm{P} 28)\end{array}$ & $\begin{array}{l}\text { Good morning. I am } \\
\text { exhausted. Any chance of } \\
\text { a cup of coffee? }\end{array}$ & $\begin{array}{l}\text { Jó reggelit! Fáuadt nulla } \\
\text { vagyok. Késhetek egy } \\
\text { csésze lóerös kévét? }\end{array}$ \\
\hline
\end{tabular}


The idiomatic phrase I am existed (meaning "I am exhausted") could have been translated with a similar idiom Hulla fáradt vagyok, which, however, would not have achieved any humorous effect. Therefore, in order to achieve semantic and pragmatic equivalence, the translator resorted to a similar verbal game. A word order change, completed with a vowel change, was employed: Hulla fáradt [lit. corpse tired] > Fáradt hulla [lit. tired corpse] > Fáradt nulla [lit. tired zero]. It is to be noted that the lexeme nulla can also refer to a person not worth anything, which actually completes the meaning of the adjective tired. Furthermore, the noun nulla in the TT is a perfect antonym for the connotation of the ST existed.

Crabtree's fatigue is to be invigorated by a nice cup of kifi [cup of coffee]. The ST phrase again operates with a vowel change but this time resulting in a nonsense. The TT, however, brings a meaningful solution. The Hungarian idiomatic phrase would sound like egy csésze jó erôs kávét [lit. a cup of good strong coffee], but - in order to create a similarly humorous effect like the ST - this was distorted with the help of a vowel change and the merging of two words, resulting in lóerös kévét [lit. horse strong sheaf].

As found in the case of frequently used words, expressions, the idiomatic phrases also contain bawdy language. In the case of the following example, the context is that René finds shelter in the building of the gendarmerie as he is hiding from a woman. He asks Crabtree to lock him up. As the fake gendarme wants some pretext to arrest him, he asks him, using an idiomatic phrase.

Table 11. Fixed expressions and idioms $V$

\begin{tabular}{lll}
\hline Mispronounced language & Meaning & Hungarian version \\
\hline Crabtree: Are you & Are you confessing to & C: Elkövetett valami \\
confessing to some & some crime? & $\begin{array}{l}\text { tösvénysestést? } \\
\text { cream? }\end{array}$ \\
$\begin{array}{l}\text { René: Yes. Cream galore! } \\
\text { (S5E7/P33) }\end{array}$ & Res, cream galore! & $\begin{array}{l}\text { Ren, söt } \\
\text { tösvénydisznót. }\end{array}$ \\
\hline
\end{tabular}

The phrase is to confess to a crime, which was mangled as confess to a cream. The meaning of the phrase is slightly changed in the TT: Elkövetett valami tösvénysestést? [lit. have you committed a law pig], where the vowel change results in a malapropism: sertés vs. sértés [pig vs. offence]. In replying to Crabtree's question, René joins the phonetic game and utters cream galore [meaning "crime in abundance"]. This reply is completely changed in the Hungarian TT. It is similarly an answer to Crabtree's question, but it tries to provide a follow-up to the previous language game, completing it with a less sophisticated synonym of the noun used in the question: Igen, sót tösvénydisznót. [lit. Yes, moreover, (I have committed) a law swine/hog.], where the Hungarian compound noun is also a nonsensical word. 
The line of fixed expressions and idioms will be concluded with one last example, where the translators resorted to the total change of the ST in the TT version. In order to understand the full conversation, I will quote a longer verbal exchange. The context is that Herr Flick of the Gestapo and his adjutant, Von Smallhausen, are disguised as fishmongers and are selling fish on the market. Crabtree walks past and asks for their licence.

Table 12. Fixed expressions and idioms VI

\begin{tabular}{lll}
\hline Mispronounced language & Meaning & Hungarian version \\
\hline Herr Flick: What part of & Herr Flick: What part & H. F: Franciaország \\
$\begin{array}{l}\text { France do you come from? } \\
\text { Crabtree: I am half }\end{array}$ & from? & melyik tájára valósi? \\
Itoolian. & Crabtree: I am half Italian. & Cogy rája. \\
Herr Flick: Itoolian? & Herr Flick: Italian? & H. F: De hova valósi? \\
Crabtree: Yes, Itoolian. & Officer Crabtree: Yes, & C: Egybesült állatok. \\
Von Smallhausen: I think & Italian. Von Smallhausen: & V. S.: Azt akarja \\
he means Italian. & I think he means Italian. & mondani, hogy amcsi. \\
Crabtree: I was brought & Officer Crabtree: I was & C: Ami csiga, azt is \\
up in Nipples. & brought up in Naples. & szehetem. \\
Herr Flick: Nipples? & Herr Flick: Naples? & H. F: És mit csinál vele? \\
Crabtree: Yes, you know & Officer Crabtree: Yes, you & C: Semmit, csak kéhtezte, \\
the old sooing? See & know the old saying? & hát mondom. De \\
Nipples and do. & "See Naples and die.” & elküldtek a fhancba. \\
(S5E15/P41) & & \\
\hline
\end{tabular}

As it can be noticed, the nation name Italian was completely omitted and was changed into another distorted nation name: egybesült állatok [lit. roast animals], representing a totally different country name, Egyesült Államok [the United States]. This transformation brings about the change of the whole context, and there is no way back to render the malapropism deriving from the idiom See Naples and die. The meaning of the phrase is too strongly culture-bound, and, unfortunately, the double meaning induced by the mispronunciation of the city name is completely lost in the Hungarian TT.

\section{Conclusions}

The in-depth analysis of Officer Crabtree's humorously distorted utterances in the English-“Fronch” original source text and its Hungarian dubbed version has led us to general and more text-specific conclusions.

Although an audiovisual text has four components, our analysis focused solely on the verbal code, both in its ST and TT variant, excluding the other three 
components. It has been proved that, like in most cases of humour translation, the main translation strategy is adaptation rather than striving for formal or literal equivalence. Further, frequently used strategies include compensation, but we can also witness substitution and omission.

It has been proved again that humour translation involves a great amount of creativity and ease on the part of the dubbing team. Our analysis might prompt translators of humorous texts to consciously and systematically view their own work with a more objective eye, regarding them less intuitively.

Crabtree's verbal manifestations are special in that his imperfect knowledge of "French" is, in actual fact, an alibi for the flood of verbal jokes which have been rendered by the Hungarian dubbing team ${ }^{17}$ with similar linguistic (mainly phonetic) games. The verbal humour is mainly nonsensical or bawdy or both, and, as a result, the Hungarian version has been found either having a neutral or containing similar taboo language both on the level of the frequently recurrent elements and of the fixed expressions and idioms. In my corpus, I have found a low number of cases where the TT was found more indecent than the ST. All these solutions reflect the openness and creative imagination of the dubbing translators. The analysed examples revealed only a few cases where the dubbing translators resorted to the total omission of the pun.

The Hungarian text is mainly characterized by an idiosyncratic Hungarian pronounced with a French accent, manifested mainly in the presence of the uvular "в" sound (instead of the rolled " $\mathrm{r}$ "), the strong nasals and lexemes deriving from French. This accent contributes to the common stereotypical view of the French within the Hungarian society.

The present study has provided a qualitative comparative analysis of Crabtree's "Fronch" language in the English source text and the Hungarian target text. As shown in the analyses, the "Hungarian" Crabtree, dubbed by the ingenious András Sinkovits-Vitay, rightfully equals the original character played by Arthur Bostrom. However, due to the excellent work of the dubbing team, Officer Crabtree's Hungarian soundtrack is also full of creative translating solutions and wordplay, contributing to the success of the series among Hungarian viewers of all time. The Hungarian dubbed version of Allo! Allo! is an unavoidable sample of the Hungarian dubbing tradition.

\section{Acknowledgements}

I would like to express my gratitude to the two anonymous reviewers for their insightful comments and observations that helped to improve the quality of my article. All remaining defects are my own responsibility.

17 By dubbing team, I refer not only to the screen translators but also to the dubbing director and the dubbing actors as well. 


\section{References}

Allan, Keith-Kate Burridge. 2006. Forbidden Words: Taboo and the Censoring of Language. Cambridge: Cambridge University Press.

Antonini, Rachele. 2005. The perception of subtitled humour in Italy. Humour. International Journal of Humour Research 18(2): 209-225.

Arampatzis, Christos. 2015. Dialects at the service of humour within the American sitcom: A challenge for the dubbing translator. In Chovanec, Jan-Isabel Ermida (eds), Language and Humour in the Media, 67-82. Newcastle-upon-Tyne: Cambridge Scholars Publishing.

Ávila-Cabrera, José Javier. 2015. Subtitling Tarantino’s offensive and taboo dialogue exchanges into European Spanish: The case of Pulp Fiction. Revista de Lingüística y Lenguas Aplicadas 10: 1-11. https://eprints.ucm.es/50078/1/3419-12795-2-PB. pdf. (Last accessed: 10 August 2020).

— 2016. The subtitling of offensive and taboo language into Spanish of 'Inglourious Basterds'. Babel 62(2): 211-232.

Baker, Mona. 2018. In Other Words: A Coursebook on Translation. $3^{\text {rd }}$ edition. London: Routledge.

Benő, Attila. 2016. Nyelvi játék és fordítás [Language play and translation]. Korunk 2016(4): 61-66.

Beseghi, Micol. 2015. WTF! Taboo Language in TV Series: An Analysis of Professional and Amateur Translation.

https://www.researchgate.net/publication/308914922_WTF_Taboo_Language_ in_TV_Series_An_Analysis_of_Professional_and_Amateur_Translation. (Last accessed: 10 August 2020).

Blake, Barry J. 2019. Taboo language as source of comedy. In Keith Allan (ed.), The Oxford Handbook of Taboo Words and Language, 353-371. Oxford: Oxford University Press.

Bogucki, Łukasz. 2013. Areas and Methods of Audiovisual Translation. Frankfurt am Main: Peter Lang.

Bucaria, Chiara. 2007. Humour and other catastrophes: Dealing with the translation of mixed TV genres. Linguistica Antverpiensia New Series, Special Issue Audiovisual Translation: A Tool for Social Integration 6: 235-254.

Camilli, Lana. 2019. The dubbing of wordplay: The case of A touch of cloth. Journal of Audiovisual Translation 2(1): 75-103.

Chaume, Frederic. 2006. Dubbing. In Encyclopedia of Language and Linguistics, 6-9. Elsevier. https://www.researchgate.net/publication/288153012_Dubbing/ stats. (Last accessed: 10 August 2020).

2013. Research paths in audiovisual translation: The case of dubbing. In Francesca Bartrina-Carmen Millán-Varela (eds), Routledge Handbook of Translation Studies, 288-302. London-New York: Routledge. 
Chiaro, Delia. 2000. Servizio completo: On the (un)translatability of puns on screen. In Bollettieri Bosinelli, Rosa Maria-Christine Heiss-Marcello Soffritti-Silvia Bernardini (eds), La traduzione multimediale: Quale traduzione per quale testo? 27-42. Bologna: CLUEB.

- 2005. Foreword: Verbally expressed humor and translation: An overview of a neglected field. HUMOR-International Journal of Humor Research 18(2): 135-145.

— 2006. Verbally expressed humour on screen: Reflections on translation and reception. The Journal of Specialised Translation 6: 198-208.

- 2007. Not in front of the children? An analysis of sex on screen in Italy. Linguistica Antverpiensia New Series, Special Issue Audiovisual Translation: A Tool for Social Integration 6: 255-276.

- 2009. Issues in Audiovisual Translation. In Jeremy Munday (ed.), The Routledge Handbook of Translation Studies, 141-165. London: Routledge.

- 2012. Translation, Humour and the Media. London: Continuum.

De Rosa, Gian Luigi-Francesca Bianchi-Antonella De Laurentiis-Elisa Perego (eds), 2014. Translating Humour in Audiovisual Texts. Frankfurt am Main: Peter Lang. Delabastita, Dirk. 1996. Introduction. In Dirk Delabastita (ed.), Special issue of The Translator: Wordplay and Translation: Essays on Punning and Translation 2(2): $1-22$.

- 2004. Wordplay as a translation problem: A linguistic perspective. In Harald Kittel-Paul Frank Armin-Norbert Greiner-Theo Hermans-Werner Koller-José Lambert-Fritz Paul (eds), Übersetzung, translation, traduction, 600-606. Berlin: Mouton de Gruyter.

2012. Language, comedy and translation in the BBC sitcom 'Allo! Allo!' In Delia Chiaro (ed.), Translation, Humour and the Media. Translation and Humour, Volume 2, 193-221. London: Continuum.

Dore, Margherita. 2020. Humour in Audiovisual Translation: Theories and Applications. London: Routledge.

Drahota-Szabó, Erzsébet. 2016. A humor fordíthatósága és fordíthatatlansága [Translatability and untranslatability of humour]. In Boda-Ujlaki, Judit-Zsuzsanna Barta-Anna T. Litovkina-Péter Barta (eds), A humor nagyítón keresztül [Humour through the Magnifying Glass], 11-22. Budapest: Tinta.

Fawcett, Peter. 1997. Translation and Language. Manchester: St. Jerome.

Gottlieb, Henrik. 2001a. Texts, translation and subtitling - In theory, and in Denmark. In Henrik Holmboe-Signe Isager (eds), Translators and Translations, 149-192. The Danish Institute at Athens: Aarhus Universitetsforlag.

— 2001b Subtitling: Visualising filmic dialogue. In Lourdes Lorenzo GarcíaAna M. Pereira (eds), Traducción subordinada (II). El subtitulado, 69-84. Vigo: Servicio de Publicaciones de la Universidad de Vigo. 
Hermans, Theo. 2019. Untranslatability, entanglement and understanding. In Large, Duncan et al. (eds), Untranslatability: Interdisciplinary Perspectives, 27-40. London and New York: Routledge.

Hughes, Geoffrey. 2006. An Encyclopedia of Swearing: The Social History of Oaths, Profanity, Foul Language, and Ethnic Slurs in the English-Speaking World. New York-London: M. E. Sharpe.

Jay, Timothy. 1992. Cursing in America. A Psycholinguistic Study of Dirty Language in the Courts, in the Movies, in the Schoolyards and on the Streets. PhiladelphiaAmsterdam: John Benjamins.

Luyken, Georg-Michael-Thomas Herbst-Jo Langham-Brown-Helen Reid-Hermann Spinhof. 1991. Overcoming Language Barriers in Television: Dubbing and Subtitling for the European Audience. Manchester: European Institute for the Media.

Martonfi, Anna-Julia Havas. 2019. Bedrock behind the Iron Curtain: Transcultural Shifts in the Hungarian Dubbed Version of the Flintstones (1960-66). https:// journal.animationstudies.org/anna-martonfi-julia-havas-bedrock-behindthe-iron-curtain-transcultural-shifts-in-the-hungarian-dubbed-version-of-theflintstones-1960-66/. (Last accessed: 20 May 2020).

McEnery, Tony. 2006. Swearing in English. Bad Language, Purity and Power from 1586 to the Present. London-New York: Routledge.

Mudriczki, Judit. 2014. Audiovisual humour strategies in the Italian, German and Hungarian dubbed versions of Shreck the Halls. In De Rosa, Gian Luigi-Francesca Bianchi-Antonella De Laurentiis-Elisa Perego (eds), Translating Humour in Audiovisual Texts, 51-66. Frankfurt am Main: Peter Lang.

Ranzato, Irene. 2016. Translating Culture Specific References on Television. The Case of Dubbing. London-New York: Routledge.

Shuttleworth, Mark-Moira Cowie. 2013. Dictionary of Translation Studies. Manchester: St Jerome Publishing.

Tóth, Menyhért. 2015. Szinkronba hozva. A magyar szinkron története. https:// www.filmtett.ro/cikk/3928/a-magyar-szinkron-tortenete. (Last accessed: 25 June 2020).

Toury, Gideon. 1995. Descriptive Translation Studies and Beyond. Amsterdam: John Benjamins.

Valdeón, Roberto A. 2018. Discourse analysis, pragmatics, multimodal analysis. In Di Giovanni, Elena-Yves Gambier (eds), Reception Studies and Audiovisual Translation, 111-132. Amsterdam/Philadelphia: John Benjamins.

Vandaele, Jeroen. 1999. 'Each time we laugh.' Translated humour in screen comedy. In Jeroen Vandaele (ed.), Translation and the (Re)Location of Meaning, 237-372. Leuven: CETRA. 
2010. Humour in translation. In Yves Gambier-Luc van Doorslaer (eds), Handbook of Translation Studies, vol. 1: 147-152. Amsterdam-Philadelphia: John Benjamins.

Veisbergs, Andrejs. 1997. The contextual use of idioms, wordplays, and translation. In Delabastita, Dirk (ed.), Traductio: Essays on Punning and Translation, 155176, Manchester: St. Jerome Publishing.

Vinay, Jean-Paul-Jean Darbelnet. 1995. Comparative Stylistics of French and English: A Methodology for Translation. Amsterdam-Philadelphia: John Benjamins.

Wajnryb, Ruth. 2005. Expletive Deleted: A Good Look at Bad Language. New York: Free Press.

Yus, Francisco. 2016. Humour and Relevance. Amsterdam: John Benjamins.

Zabalbeascoa, Patrick. 1996. Translating jokes for dubbed television situation comedies. In Dirk Delabastita (ed.), Special issue of The Translator: Wordplay and Translation: Essays on Punning and Translation 2(2): 235-257.

2008. The nature of the audiovisual text and its parameters. In Díaz-Cintas, Jorge (ed.), The Didactics of Audiovisual Translation, 21-37. Amsterdam/ Philadelphia: John Benjamins.

Zolczer Péter. 2016. Translating humour in audiovisual media. European Journal of Humour Research 4(1): 76-92. 